\title{
RESTORING ELECTRICITY USE WITH THE SPOLIATION REMEDY: A CRITICAL COMMENT ON ESKOM HOLDINGS SOC LTD V MASINDA
}

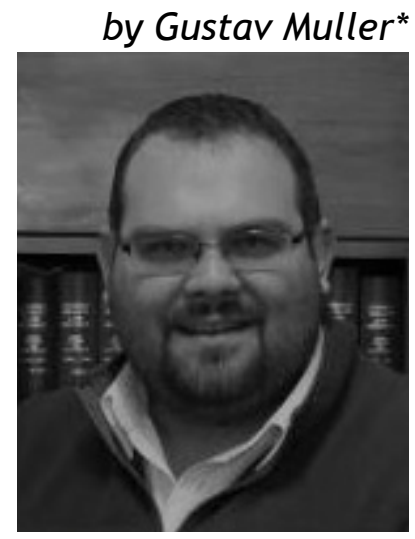

\section{Introduction}

In Eskom Holdings SOC Ltd $v$ Masinda' ('Masinda') teams from the appellant removed various illegal connections to the national electricity reticulation grid. The removal was animated by a concern for the well-being of those people living in homes with illegal connections and to prevent damage to their property as a result of these dangerous connections. ${ }^{2}$ While the exact reasons for the removal of the illegal connections were not clearly articulated in the appellant's submissions, it appears that the connections constituted an immediate danger to the public because the equipment were too small; it did not meet the prescribed quality standards; and it was not installed by an authorised contractor. ${ }^{3}$ The respondent argued that she used the electricity in her home by drawing supply through a prepaid meter and that this supply constituted an incident of her occupation. She successfully sought the restoration ante omnia of the electricity supply to her home in the Eastern Cape Division of the High Court, Mtatha. ${ }^{4}$ On appeal Leach JA reasoned that it could not have

* $\quad$ LLB LLD (Stellenbosch University), Diploma (Åbo Akademi). Senior Lecturer in the Department of Private Law, University of Pretoria. ORCID: 0000-0003-1254-6601.

12019 (5) SA 386 (SCA).

2 Masinda par 2.

3 Masinda par 3.

4 Masinda par 9. 
been the intention of the court $a$ quo to order the restoration ante omnia of a connection 'that was unlawful and a danger to the public.' Restoration ante omnia that 'complied with the necessary requirements of safety' would not only have required the appellant to do something more than restoring the property to its former state, ${ }^{5}$ but also extended the purpose of the spoliation remedy to include the 'reconstituted equivalent' 6 of the specified property. ${ }^{7}$ However, if the court $a$ quo intended the restoration ante omnia of an unlawful and dangerous electricity supply, ${ }^{8}$ the further difficulty would be that the order would be directing the appellant to 'commit an illegality' which itself would be sufficient for a court to refuse the spoliation remedy. ${ }^{9}$ Finally, Leach JA reasoned that the mere existence of an electricity reticulation supply in the respondent's home is insufficient to afford her a right that qualified as an incident of her occupation. ${ }^{10}$ He therefore upheld the appeal ${ }^{11}$ and dismissed the respondents 'terse' claim as 'misplaced' and 'insufficient'. ${ }^{12}$

In this article I provide a critical comment on the Masinda judgment. I seek to do so by providing a brief exposition of the importance of having access to and being able to stop unlawful interfere with your access to electricity in part 2. In part 3 I set out the requirements, features and application of the mandament van spolie. This is followed in part 4 with an analysis of the growing jurisprudence (comprising two high court judgments that predate democracy and two judgments from the Supreme Court of Appeal in the past decade) where the mandament van spolie was used to seek restoration ante omnia of electricity use.

\section{The importance of electricity from a human rights perspective}

In Government of the Republic of South Africa $v$ Grootboom ${ }^{13}$ (Grootboom), Yacoob J provided a nuanced exposition of the obligations that flow from section 26 of the Constitution. In his analysis the right of access to adequate housing entails 'more than bricks and mortar’. Importantly, this includes access to:

$5 \quad$ See Zinman v Miller 1956 (3) SA 8 (T).

6 Tswelopele Non-Profit Organisation v City of Tshwane Metropolitan Municipality 2007 (6) SA 511 (SCA) par 24. See also Ngomane $v$ City of Johannesburg Metropolitan Municipality [2019] 3 All SA 69 (SCA) par 18-20 and Rikhotso $v$ Northcliff Ceramics 1997 (1) SA 526 (W) at 535B-C.

7 Masinda par 10.

8 Masinda par 12.

9 Masinda par 13.

10 Masinda par 22

11 Masinda par 27.

12 Masinda par 24

132001 (1) SA 46 (CC). 
available land, appropriate services such as the provision of water and the removal of sewage and the financing of all of these, including the building of the house itself. For a person to have access to adequate housing all of these conditions need to be met: there must be land, there must be services, [and] there must be a dwelling. ${ }^{14}$

Yacoob J's description of what it means to have access to adequate housing in South Africa - in particular, services like electricity resembles $^{15}$ one of the characteristics that the United Nations Committee on Economic, Social and Cultural Rights ${ }^{16}$ ('CESCR') identified as being indicative of having access to housing for purposes of article $11(1)^{17}$ of the International Covenant on Economic, Social and Cultural Rights ${ }^{18}$ ('ICESCR'). Housing, according to the CESCR, will be considered adequate if it inter alia provides access to:

certain facilities essential for health, security, comfort and nutrition. All beneficiaries of the right to adequate housing should have sustainable access to natural and common resources, safe drinking water, energy for cooking, heating and lighting, sanitation and washing facilities, means of food storage, refuse disposal, site drainage and emergency services. ${ }^{19}$

Conceptualising access to services - like and electricity - as an integral part of the right of access to adequate housing reinforces Yacoob J's contextual approach to the interpretation of section 26 of the Constitution. ${ }^{20}$ On the one hand, the approach forges explicit textual links with section 32 of the Constitution. ${ }^{21}$ In doing so the

14 Grootboom par 35 (emphasis added).

15 Despite the 'significant' textual differences that Yacoob J enumerated in Grootboom par 28.

16 The committee consists of 18 experts with internationally recognised competence in the field of human rights who serve in their personal capacity for a renewable four year term. The primary task of the Committee is to assist the Economic and Social Council with its consideration of the reports that States Parties submit to the Secretary-General of the United Nations (article 16(2) of the ICSECR).

17 Article 11(1) of the ICESCR, which affords everyone the right to an adequate standard of living, reads:

'The States Parties to the Present Covenant recognize the right of everyone to an adequate standard of living for himself and his family, including adequate food, clothing and housing, and to the continuous improvement of living conditions. The States Parties will take appropriate steps to ensure the realization of this right, recognizing to this effect the essential importance of international cooperation based on free consent.'

18993 UNTS 3. The Covenant was adopted by the General Assembly of the United Nations on 16 December 1966 and came into force on 3 January 1976. As at 19 June 2019, the Covenant has been ratified by 169 countries. South Africa signed the Covenant on 3 October 1994 and ratified it on 15 January 2015.

19 CESCR General Comment 4: The right to adequate housing (Art 11(1)), UN Doc E/ C 1992/23 (1991) par 8(b).

20 Grootboom par 21.

21 Section 32(1) of the Constitution affords everyone 'the right of access to - (a) any information held by the state; and any information that is held by another person and that is required for the exercise or protection of any rights.' The Promotion of Access to Information Act 2 of 2000 was enacted to give effect to section 32(2) of the Constitution. See, in general, Currie I and De Waal J The Bill of Rights Handbook 6th ed (2013) chapter 30; Klaaren J and Penfold G 'Access to Information' in Woolman S, Bishop M and Brickhill J (eds) Constitutional Law of South Africa 2 nd ed, chapter 62. 
conceptualisation affirms the interrelated, interconnected and mutually supporting nature of all the rights in the Bill of Rights. ${ }^{22}$ On the other hand, the approach highlights the social and historical context against which the denial of access to electricity ${ }^{23}$ (including as a source of energy for cooking) ${ }^{24}$ should be interpreted.

The Constitution states that it is one of the objects of local government to ensure the provision of basic services to communities ${ }^{25}$ in an equitable and sustainable manner. ${ }^{26}$ The power to realise these basic services have been assigned to local governments in terms of two important statutes: ${ }^{27}$ the Housing Act 107 of $1997^{28}$ and the Local

22 See, in general, Liebenberg S Socio-economics rights: Adjudication under a transformative constitution (2010) 51-54 and the sources cited there.

23 White Paper par 3.1.4(c) estimated that $46.5 \%$ of all households did not have a link to the electricity supply grid in 1994. The latest statistics from Statistics South Africa indicate that the percentage of households in South Africa that are connected to the mains electricity supply increased by $7,7 \%$ (or 5.086 million households) from 76,7\% (or 8.586 million households) in 2002 to $84,4 \%$ (or 13.672 million households) in 2017. See Statistics South Africa Statistical Release P0318, General Household Survey 2017 (2019) 32.

24 The percentage of households in South Africa that use their connection to the mains electricity supply for cooking increased by $18,4 \%$ (or 5.858 million households) from 57,5\% (or 6.437 million households) in 2002 to 75,9\% (or 12.295 million households) in 2017. As a result there was a simultaneous decline in the percentage of households that use paraffin $(11,9 \%$ or 1.122 million households), wood $(11,6 \%$ or 0.878 million households) and coal $(2,6 \%$ or 0.271 million households). However, the increase in the percentage of people that use gas $(2 \%$ or 0.434 million households) for cooking over the same period is an interesting development. See Statistics South Africa Statistical Release P0318, General Household Survey 2017 (2019) 33.

25 Section 152(1)(b), read with section 153, of the Constitution. The range of basic municipal services that a municipality should provide includes, in terms of schedule $4 \mathrm{~B}$ of the Constitution, electricity and gas reticulation; municipal health services; municipal public transport; municipal public works; stormwater management systems in built-up areas; and water and sanitation services limited to potable water supply systems and domestic waste-water and sewage disposal systems. Schedule $5 B$ of the Constitution adds cleansing; local amenities; municipal parks and recreation; municipal roads; refuse removal, refuse dumps and solid waste disposal; and street lighting.

26 Section 155(4) of the Constitution.

27 Section 156(1) and (4) read with sections $155(6)$ and (7) of the Constitution. See Muller $\mathrm{G}$ and Liebenberg $\mathrm{S}$ 'Developing the law of joinder in the context and evictions of people from their homes' (2013) 29 SAJHR 554-570 559-565 for a brief overview of these statutes.

28 The long title of the Act states that the purpose of the Act is to facilitate sustainable housing development. Section 1 of the Act defines 'housing development' as 'the establishment and maintenance of habitable, stable and sustainable public and private residential environments to ensure viable households and communities in areas allowing convenient access to economic opportunities, and to health, educational and social amenities in which all citizens and permanent residents of the Republic will, on a progressive basis, have access to - (b) potable water, adequate sanitary facilities and domestic energy supply'. Section 9(1) of the Act imposes a peremptory obligation of local governments to '(a) ensure that - (iii) services in respect of water, sanitation, electricity, roads, stormwater drainage and transport are provided in a manner which is economically efficient' and '(g) provide bulk engineering services, and revenue generating services in so far as such services are not provided by specialist utility suppliers'. 
Government: Municipal Systems Act 32 of $2000 .^{29}$ The Constitution and these framework statutes create a 'special cluster of relationships' 30 that exist between individuals and the municipalities which are mandated to facilitate access to these services. However, despite the 'public law nature' 31 of these services, property law principles play a significant role in obtaining access to statutory utility rights $^{32}$ and protecting individuals from unlawful interferences with their use of these services.

\section{Quasi-possessio of incorporeals}

The spoliation remedy (or mandament van spolie) requires the spoliator to restore the applicant (spoliatus) to the position she was in prior to the dispossession. ${ }^{33}$ The nature of the spoliation remedy is to protect stable property relations from infringements in the context of unlawful dispossession. ${ }^{34}$ The foundational principle of the spoliation remedy is that control must be restored to the dispossessed party before all else (spoliatus ante omnia restituendus est). To that end the purpose of the spoliation remedy is to discourage self-help by restoring possession that was lost as a result of spoliation. ${ }^{35}$

29 The long title of the Act states that purpose of the Act is to enable local authorities to move progressively towards the social and economic upliftment of communities, and to ensure that these communities obtain universal access to abovementioned basic services. Section 1 of the Act defines 'basic municipal services' as 'a municipal service that is necessary to ensure an acceptable and reasonable quality of life and, if not provided, would endanger public health or safety or the environment.' Section 73(1)(c) of the Systems Act places a peremptory obligation of local governments to ensure that all residents of the community have access to at least the minimum level of basic municipal services. Section 73(2) states that these municipal services must: (a) be equitable and accessible; (b) be provided in a manner that is conducive to (i) the prudent, economic, efficient and effective use of available resources, and (ii) the improvement of standards of quality over time; (c) be financially sustainable; (d) be environmentally sustainable; and (e) be regularly reviewed with a view of upgrading, extending and improving the service.

30 Residents of Joe Slovo Community, Western Cape v Thubelisha Homes 2010 (3) SA 454 (CC) par 343.

31 Joseph $v$ City of Johannesburg 2010 (4) SA 55 (CC). In this case the electricityservice provider that is wholly-owned by the City of Johannesburg, City Power (Pty) Ltd, terminated the electricity supply to the applicants' homes because their landlord owed it a substantial amount of money. The Constitutional Court was asked to consider whether any legal relationship existed between the applicants and City Power, beyond the contractual relationship that existed between City Power and the landlord, and whether that relationship (between service provider and consumer) would entitle the applicants to procedura fairness in terms of s 3(2)(b) of the Promotion of Administrative Justice Act 3 of 2000 (PAJA).

32 In terms of the Water Services Act 107 of 1998; the National Water Act 36 of 1998 ; the Electricity Regulation Act 4 of 2006 and the Electronic Communications Act 36 of 2005.

33 Boggenpoel ZT Property Remedies (2017) 94.

34 Van der Walt AJ 'Squatting, spoliation orders and the new constitutional order' (1997) 60 THRHR 522-529 525.

35 Kleyn DG 'The protection of quasi-possession in South African law' in Descheemaeker E (ed) The consequences of possession (2014) 185-210 187. 
The spoliation remedy is characterised by the fact that it is an extraordinarily robust, speedy and temporary remedy. Its robustness flows from its singular purpose to effect ante omnia restoration of possession. ${ }^{36}$ To that end there are few requirements which the spoliatus should be able to satisfy on a balance of probabilities with relative ease. The onus then shifts to the respondent to raise a defence $^{37}$ against the operation of the remedy if the spoliatus is successful in proving the constituting requirements. Once these requirements have been established a court has no discretion to preclude the operation of the remedy based on the balance of convenience $^{38}$ to the parties or apparent injustice of restoring possession to the spoliatus. ${ }^{39}$ The remedy is speedy because it is instituted by way of motion procedure and usually takes the form of a special ex parte or urgent application proceeding. The speediness of the remedy is enhanced by the fact that the court may not consider the merits, including the wrongfulness and illegality of the control, during the proceedings. ${ }^{40}$ This characteristic makes the remedy particularly attractive and ensures that the restoration of possession ante omnia is effected 'without unnecessary delays.' 41 While the spoliation order is final, the restoration ante omnia also makes it provisional in nature ${ }^{42}$ because the merits of the dispute will be evaluated by a court in any subsequent petitory action (iudicium petitorium). ${ }^{43}$ The threat of the spoliation order serves as a warning to any person who can assert a real right in terms of a particular thing to rather take recourse to the courts of law and not to succumb to the allure of self-help. ${ }^{44}$

36 Boggenpoel ZT Property Remedies (2017) 98.

37 See Boggenpoel ZT Property Remedies (2017) 128-153 and Badenhorst PJ, Pienaar JM and Mostert H Silberberg and Schoeman's The Law of Property 5th (2006) 302 308. Taitz J 'spoliation proceedings and the "grubby-handed" possessor' (1981) 98 SALJ 36-41 indicates that there are a limited number of defences that can be raised against the spoliation remedy and argues that there is no reason why the list of defences should be expanded. However, Van der Walt AJ 'Defences in spoliation proceedings' (1985) 102 SALJ 172-180 argues that the developing spoliation jurisprudence may have opened up the possibility that other defences could be raised against the operation of the remedy.

38 Beukes v Crouse 1975 (4) SA 215 (NC) at 218 and Runsin Properties (Pty) Ltd v Ferreira 1982 (1) SA 658 (SE) at 670. However, in Parker v Mobil Oil of Southern Africa (Pty) Ltd 1979 (4) SA 250 (NC) the court refused to grant the remedy on the basis that restoration ante omnia would cause extreme hardship to the respondent and would in any event be of no use to the applicant.

39 Boggenpoel ZT Property Remedies (2017) 99-100.

40 See Ivanov v North West Gambling Board 2012 (6) SA 67 (SCA).

41 Boggenpoel ZT Property Remedies (2017) 100.

42 Boggenpoel ZT Property Remedies (2017) 98. Contrast Eskom v Nikelo [2018] ZAECMHC 48 (21 August 2018).

43 Kleyn DG 'The protection of quasi-possession in South African law' in Descheemaeker E (ed) The consequences of possession (2014) 185-210 187.

44 Muller G The impact of section 26 of the Constitution on the eviction of unlawful squatters in South African law (unpublished LLD dissertation, Stellenbosch University, 2011) 60-63 and Muller G 'The legal-historical context of urban forced evictions in South Africa' (2013) 19 Fundamina 367-396 386-387. 
To succeed with the spoliation remedy the applicant must prove that she was in peaceful and undisturbed possession of the property; and that she was unlawfully dispossessed. ${ }^{45}$ For purposes of the first requirement the applicant must prove that her possession was stable and enduring. Stated differently, the possession must have been sufficiently established so that the law may attach legal consequences to it. ${ }^{46}$ It is trite that possession requires the existence of both the factual control (corpus) over the property 47 and an outward manifestation of the appropriate mental attitude (animus) towards the property. ${ }^{48}$ The applicant must therefore have had effective control over the property ${ }^{49}$ coupled with the intention to draw a benefit from the thing by exercising physical control over it (animus sibi habendi). ${ }^{50}$ For purposes of the second requirement the applicant must prove two aspects. First, there must be some form of dispossession of the whole or part of the property. ${ }^{51}$ The dispossession must be of such a nature that the interference, whether 'substantial and serious' 52 or a 'mere disturbance', 53 affects the ability of the applicant to use the property. Second, the dispossession must furthermore be characterised by the fact that it was done 'forcibly or wrongfully' and without the consent of the applicant. ${ }^{54}$ The nonconsensual nature of the dispossession can additionally flow from the fact that the dispossession is possible in terms of the common law defence of counter spoliation; or because it is authorised by legislation ${ }^{55}$ or executed in terms of an order of court. ${ }^{56}$

45 Nino Bonino v De Lange 1906 TS 120 and Yeko $v$ Qana 1973 (4) SA 735 (A) at 739.

46 Ness $v$ Greef 1985 (4) SA 641 (C) at 647.

47 Badenhorst PJ, Pienaar JM and Mostert H Silberberg and Schoeman's The Law of Property 5ed (2006) 276-279; Sonnekus JC and Neels JL Sakereg Vonnisbundel 2de uitg (1994) 127-130; Van der Merwe CG Sakereg 2nd ed (1989) 97-103.

48 Badenhorst PJ, Pienaar JM and Mostert H Silberberg and Schoeman's The Law of Property 5ed (2006) 279-284; Sonnekus JC and Neels JL Sakereg Vonnisbundel 2de uitg (1994) 130-132; Van der Merwe CG Sakereg 2nd ed (1989) 103-107

49 CG van der Merwe 'Things' in LTC Harms \& JA Faris JA (eds) The Law of South Africa vol 27 (2nd ed 2014) par 108; Badenhorst PJ, Pienaar JM and Mostert H Silberberg and Schoeman's The Law of Property 5ed (2006) 295

50 Yeko v Qana 1973 (4) SA 735 (A) at 739.

51 Bennett Pringle (Pty) Ltd v Adelaide Municipality 1977 (1) SA 230 (E) at 233.

52 Burger $v$ Van Rooyen 1961 (1) SA 159 (0) at 160-161.

53 Pienaar v Matjhabeng Plaaslike Munisipaliteit [2012] ZAFSHC 213 (22 November 2012) par 11.

54 Nino Bonino v De Lange 1906 TS 120 at 122

55 In Erasmus v De Villiers Berrange NO [2013] ZAFSHC 149 (10 September 2013) the applicant challenged the lawfulness of a warrant to attach cows in terms of section 69(3) of the Insolvency Act 24 of 1936. In Elias Dunias t/a Colosseum Internet Lounde $v$ Minister of Safety and Security [2013] ZAKZNPHC 55 (17 October 2013) the applicant's cash, equipment and documents were seized for an alleged violation of the National Gambling Act 7 of 2004 and the KwaZuluNatal Gaming and Betting Act 8 of 2010.

56 Boggenpoel ZT Property Remedies (2017) 123. 
The application of the spoliation remedy to use rights is controversial $^{57}$ because their intangible nature makes it impossible to physically hold or control the objects of these incorporeal rights. The law therefore recognises the control of such objects through the notion of quasi-control. However, the spoliation remedy only protects the quasi-control of certain rights because it was never intended to have a 'catch-all' function to protect the quasi-control of all types of rights. ${ }^{58}$ If this were possible, litigants could rely on this remedy to enforce all personal rights (instead of specific performance in contract law), which would collapse the distinction between property law and the law of contract. ${ }^{59}$ For purposes of this extended application of the spoliation remedy the central question is therefore always whether quasi-control of a particular right enjoys protection under this remedy. Finally, it must be noted that what the spoliation remedy protects here is not the rights themselves, but rather the factual status quo of exercising these rights. ${ }^{60}$

From case law it is clear that the spoliation remedy protects the quasi-control of two types of rights, namely servitudal rights and incidents of occupation. ${ }^{61}$ While it is not always possible to draw a sharp distinction between the two rights, the former concern rights which are servitudal in nature while the latter pertain to rights which are incidental to (or a component of) the control of a tangible object. ${ }^{62}$ Kleyn observes that the jurisprudence in this area of the law in practice arise because the rights exercised by the spoliatus is in doubt or the spoliatus allegedly defaulted on the payment of contractual fees for the provision of these services. ${ }^{63}$ Another instance, which is closely linked to the latter, is that the disconnection of these services is an overt attempt by the spoliator to constructively evict the spoliatus without a court order.

57 See Telkom SA Ltd v Xsinet (Pty) Ltd 2003 (5) SA 309 (SCA) par 9 and DG Kleyn 'The protection of quasi-possession in South African law' in E Descheemaeker (ed) The consequences of possession (2014) 193-194.

58 Zulu $\vee$ Minister of Works, KwaZulu, and Others 1992 (1) SA 181 (D) 188 and Firstrand Ltd t/a Rand Mercant Bank v Scholtz NO 2008 (2) SA 503 (SCA) par 13 (footnotes omitted).

59 DG Kleyn 'The protection of quasi-possession in South African law' in $\mathrm{E}$ Descheemaeker (ed) The consequences of possession (2014) 185-210 195; JC Sonnekus \& JL Neels Sakereg Vonnisbundel (2nd ed 1994) $168 \mathrm{ff}$.

60 Shoprite Checkers Ltd v Pangbourne Properties Ltd 1994 (1) SA 616 (W).

61 ZT Boggenpoel Property Remedies (2017) 107; CG van der Merwe 'Things' in LTC Harms \& JA Faris JA (eds) The Law of South Africa vol 27 (2nd ed 2014) paras 97-98 ff; DG Kleyn 'The protection of quasi-possession in South African law' in E Descheemaeker (ed) The consequences of possession (2014) $198 \mathrm{ff}$.

62 ZT Boggenpoel Property Remedies (2017) 113-114; CG van der Merwe 'Things' in LTC Harms \& JA Faris JA (eds) The Law of South Africa vol 27 (2nd ed 2014) par 99.

63 DG Kleyn 'The protection of quasi-possession in South African law' in E Descheemaeker (ed) The consequences of possession (2014) 185-210 188. 


\section{Analysis}

\section{Earlier case law on electricity}

In Froman v Herbmore Timber \& Hardware 64 ('Froman') the applicant purchased a sectional title unit from the respondent and took occupation of the unit before the transfer was registered. ${ }^{65}$ Their agreement made provision for the payment of the following costs by the applicant until the transfer was registered: occupational rent, a monthly levy, and the water and electricity usage. ${ }^{66}$ Approximately five weeks after the agreement was concluded the respondent cancelled the contract because the applicant allegedly defaulted on the payment of the water and electricity usage. ${ }^{67}$ The applicant disputed that he defaulted on the payment and subsequently also refused to vacate the unit. The respondent then disconnected the water supply and electricity reticulation to the unit. When the applicant reconnected these services the respondent retaliated by not only severing the connection to the services completely, but also removed the front door of the unit and an internal sliding door. ${ }^{68}$ The court, approvingly citing previous case law $^{69}$ and old authorities, ${ }^{70}$ held that the disconnection of the water supply and electricity reticulation 'amounted to an unlawful deprivation of applicant's possession of a right. ${ }^{71}$ O'Donovan $\mathrm{J}$ also held that the respondent took the law into its own hands by removing the doors in an attempt to execute a constructive eviction. ${ }^{72}$ The court ordered the respondent to reconnect the services and to the reinstall the doors so as to restore the status quo ante. ${ }^{73}$

In Naidoo $v$ Moodley ${ }^{74}$ ('Naidoo') the appellant leased the first floor of a double storey residence to the respondent. The respondent was under an obligation to pay the lease amount and a flat rate for electricity usage every month. ${ }^{75}$ The appellant terminated the lease a year later, but the respondent refused to vacate the residence. Protracted negotiations ensued and a settlement was concluded that would see the respondent vacate the residence four months after the

Froman at $610 \mathrm{~A}-\mathrm{B}$.

Froman at 610B.

Froman at 610C-D.

Froman at 610E-F.

69 Nino Bonino v De Lange 1906 TS 120; Painter v Strauss 1951 (3) SA 307 (0); and Nisenbaum v Express Buildings (Pty) Ltd 1953 (1) SA 246 (W).

70 Wassenaar Prac Jud chapter 14 article 1 ('eenige goederen of gerechtigheden') and Voet 43.16.7.

71 Froman at 611D.

72 Froman at 611E.

73 Froman at $611 \mathrm{~F}$.

741982 (4) SA 82 (T).

75 Naidoo at 83D. 
lease was terminated. ${ }^{76}$ The appellant finally disconnected the electricity supply to the first floor a month after the respondent again refused to vacate the residence. ${ }^{77}$ While the appellant denied that the respondent was unlawfully deprived of his right to use the electricity in the residence, he conceded that the disconnection was effected deliberately by switching off the supply on the distribution box on the ground floor of the residence. ${ }^{78}$ The appellant argued that the respondent could not frame a claim for specific performance in terms of a contract - the restoration of the electricity supply - under the guise of the spoliation remedy. However, Eloff $\mathrm{J}$ reasoned that 'the use of electricity was an incident of occupation' which the respondent had possession of through the occupation of the first floor of the residence and 'by using its appurtenances, including electrical installations and power. ${ }^{79^{\circ}}$ As a result, he held that it was 'immaterial' whether the contractual right to use electricity was severable from the lease. The court placed significant emphasis on the fact that the respondent used the electricity until the appellant disconnected the reticulation to the first floor. In dismissing the appeal the court held that the appellant's deliberate disconnection of the electricity supply 'substantially interfered' with the respondent's occupation of the first floor of the residence. ${ }^{80}$

In Rademan $v$ Moqhaka Municipality 81 ('Rademan') the appellant and other members of the Moqhaka Ratepayers and Residents Association withheld payments of their municipal taxes and levies with the hope that the local government would attend to their concerns about poor service delivery. The appellant continued to pay for the supply of water and sanitation, electricity reticulation and refuse removal services. In response the local government disconnected the supply of electricity reticulation to her home in August 2009 in an attempt to enforce payment of her outstanding municipal account in the amount of nearly R3000. The appellant successfully launched an urgent application for the restoration of the electricity reticulation supply to her home in the Magistrates' Court in Kroonstad, but this was subsequently overturned by the Free State Division of the High Court, Bloemfontein on appeal. ${ }^{82}$ It is in an appeal against this latter judgment that the appellant asked the Supreme Court of Appeal to decide whether the local government lawfully disconnected the electricity reticulation supply to her home without a court order. The appellant argued that the disconnection amounted to spoliation and that the she was entitled to the restoration ante 
omnia of the electricity reticulation supply to her home. ${ }^{83}$ However, the court agreed with the respondent's argument that the Local Government: Municipal Systems Act 32 of 2000 permits it to: levy and collect municipal rates and taxes; ${ }^{84}$ enforce payment if any account is in arrears; ${ }^{85}$ and that the regulatory framework did not require an order of court to effect the disconnection. ${ }^{86}$ The court held that it is 'both unrealistic and untenable' for municipalities to approach a court each time a user defaults on her municipal account in order to obtain an order directing it to terminate the services. ${ }^{87}$ The credit control and debt collection regulatory framework that flows from the Systems Act and the Bylaws of respective municipalities must enable it to 'collect all moneys that are due and payable to them in the most cost-effective manner.' 88 The court cited with approval the dicta of Yacoob $\mathrm{J}$ in Mkontwana where it was emphasised that:

municipalities are obliged to provide water and electricity and that it is therefore important for unpaid municipal debt to be reduced by all legitimate means. It bears repeating that the purpose is laudable, has the potential to encourage regular payments of consumption charges, contributes to the effective discharge by municipalities of their obligations and encourages owners of property to fulfil their civic responsibility. ${ }^{89}$

83 Rademan par 4. The court dismissed the alternative argument that the local government failed to afford her 14 days' notice similar to that which the Constitutional Court granted the tenants in Joseph because the facts were distinguishable in that the tenants did not have a contract with the local government.

84 Rademan paras 5, 7-9. Section 229(1) of the Constitution read with section 5(1)(g) which affords members of local government the right 'to have access to municipal services' provided that they comply with the obligation 'to pay promptly service fees, surcharges on fees, rates on property and other taxes, levies and duties imposed by the municipality' in terms of section $5(2)(b)$ of the Systems Act.

85 Rademan paras 5, 10-14. Section 96 of the Systems Act states that '[a] municipality - (a) must collect all money that is due and payable to it, subject to this Act and any other applicable legislation; and (b) for this purpose, must adopt, maintain and implement a credit control and debt collection policy which is consistent with its rates and tariff policies and complies with the provisions of this Act.' Section 97(1) of the Systems Act adds that a credit and debt collection policy must provide for "' $(\mathrm{g})$ termination of services or the restriction of the provision of services when payments are in arrears.' The Credit Control and Debt Collection Bylaws (14 May 2004) of Moqhaka City was adopted to give effect to the Systems Act and section 25 of the Bylaws empowers the local government to '(1) ... restrict or disconnect the supply of water and electricity or discontinue any other service to any premises whenever a user of any service - (a) [f]ails to make full payment on the due date or fails to make acceptable arrangements for the repayments of any amount for services, rates or taxes.' See also section 102(1)(a) of the Systems Act which allows for the consolidation of separate municipal accounts and section 25(3) of the Bylaw which adds that the right to restrict, disconnect or terminate any service as a result of non-payment will prevail notwithstanding the fact that payment may have been made in respect of some other service.

86 Rademan par 5 and 21.

87 Rademan par 16.

88 Rademan par 17.

89 Mkontwana par 52. 
This civic responsibility preclude residents from cherry-picking the accounts they would like to pay in a strategic endeavour to frustrate the optimal governance of a municipality and prevent it from fulfilling its wide-ranging constitutional obligations that must be funded by the overall revenue collected from all residents. ${ }^{90}$ Furthermore, the court situated the resident's obligation to pay for all municipal services within a carefully-grafted supply chain which includes the respective municipalities and other suppliers like, in this particular matter, Eskom. ${ }^{91}$ The court, rather dismissively, remarked that the prevalence of demonstrations about poor service delivery ${ }^{92}$ was largely attributable to the fact that residents fail to appreciate that services can only be delivered by the respective municipalities if residents pay all their municipal accounts. ${ }^{93}$ The court emphasised this point with reference to Pretoria City Council v Walker ${ }^{94}$ where the Constitutional Court stated that:

Local government is as important a tier of public administration as any. It has to continue functioning for the common good; it, however, cannot do so efficiently and effectively if every person who has a grievance about the conduct of a public official or a governmental structure were to take the law into his or her own hands or resort to self-help by withholding payment for services rendered. That conduct carries with it the potential for chaos and anarchy and can therefore not be appropriate.

In dismissing the appeal, 95 the court resolved not to determine whether the spoliation remedy was applicable to situations where personal use rights to municipal services flow from legislation or from a contractual relationship. ${ }^{96}$

Naidoo and Froman were arguably decided correctly in that both judgments found a mere interference with the factual use of electricity reticulation to be sufficient for the spoliation remedy to find application. ${ }^{97}$ Furthermore, neither judgments attached any significance to the relative right to use electricity reticulation ${ }^{98}$ or possessory interests (a lawful occupiers in Froman and an unlawful

90 Rademan par 19.

91 Rademan par 20.

92 See Muller $G$ The impact of section 26 of the Constitution on the eviction of unlawful squatters in South African law (unpublished LLD dissertation, Stellenbosch University, 2011) 15.

93 Rademan par 20.

941998 (2) SA 363 (CC).

95 Rademan par 23.

96 Rademan par 22.

97 See Nienaber v Stuckey 1946 AD 1049 at 1059 and Burger v Van Rooyen 1961 (1) SA 159 (0) at 160G-161A. See also Van der Walt AJ 'Nog eens Naidoo v Moodley - ' $n$ repliek' (1984) 47 THRHR 429-439 430.

98 Compare Coetzee v Coetzee 1982 (1) SA 933 (C) at 935D and Parker v Mobil Oil of South Africa 1979 (4) SA 250 (NC) at 255C-E where the courts held that this was an important consideration. 
occupier in Naidoo) of the applicants. ${ }^{99}$ Froman and Naidoo must be distinguished from Rademan and Masinda in that an organ of state 100 (a municipality and a state-owned enterprise respectively) effected the disconnection. Yet, it is questionable whether the journey that the Supreme Court of Appeal chose to arrive at this destination is the most appropriate one in terms of a single legal system. ${ }^{101}$

The court's reasoning in Rademan is flawless but for the finding that the spoliation was lawful in terms of the regulatory framework that the Systems Act creates. The law requires strict adherence to the authorising provisions in a statute that permits dispossession ${ }^{102}$ and 'full compliance with all the prescribed formalities and procedures to ensure that the deprivation does not amount to unlawful spoliation.' 103 Any statute that authorises a person (natural or juristic) to take the law into their own hands will be interpreted restrictively. ${ }^{104}$ In this regard it is noteworthy that both section 97(1)(g) of the Systems Act and section 25(1) of the Bylaws make provision for the restriction of electricity supply as an alternative to the disconnection or termination of the service. As a result Rademan should arguably have been decided along a similar line as City of Cape Town v Strümpher ${ }^{105}$ where the Supreme Court of Appeal reinstated water services to a caravan park because the discontinuation was not 'fair and equitable' in terms of section 4(3)(a) of the WSA. In this alternative arc the court should have acknowledged that the applicant was in peaceful and undisturbed possession of the electricity reticulation supply to her home. Additionally, the court should have allowed the operation of the spoliation on the basis that

99 See Mankowitz v Loewenthal 1982 (3) SA 758 (A); Yeko v Qana 1973 (4) SA 735 (A); Ntai v Vereeniging Town Council 1953 (4) SA 579 (A); Dönges v Dadoo 1950 (2) SA 321 (A); Van Eck and Van Rensburg v Etna Stores 1947 (2) SA 984 (A); and Nino Bonino v De Lange 1906 TS 120. See also Van der Walt AJ 'Naidoo v Moodley 1982 4 SA 82 (T) - mandament van spolie' (1983) 46 THRHR 237-240 239.

100 Section 239 of the Constitution defines an 'organ of state' as '(a) any department of state or administration in the national, provincial or local sphere of government; or (b) any other functionary or institution - (i) exercising a power or performing a function in terms of the Constitution or a provincial constitution; or (ii) exercising a public power or performing a public function in terms of any legislation, but does not include a court or a judicial officer.'

101 I borrow this metaphor from Boggenpoel ZT 'Can the journey affect the destination? A single system of law approach to property remedies' (2016) 32 SAJHR 71-86.

102 Boggenpoel ZT Property Remedies (2017) 123 and Tsegeya $v$ Minister of Police 2018 JDR 1377 (ECM).

103 Boggenpoel ZT Property Remedies (2017) 128 and Impala Water Users Association $v$ Lourens NO and Others 2008 (2) SA 495 (SCA) par 9. On this requirement, see the conflicting decisions in Van Rhyn and Others NNO V Fleurbaix Farm (Pty) Ltd 2013 (5) SA 521 (WCC) and Knox and Another $v$ Second Lifestyle Properties (Pty) Ltd and Another (A28/2011) [2012] ZAGPPHC 223 (11 October 2012) and the discussion by Boggenpoel ZT Property Remedies (2017) 125-127.

104 See, for instance, Midvaal Local Municipality v Meyerton Golf Club 2014 JDR 2243 (GJ); African Billboard Advertising (Pty) Ltd $\vee$ North and South Central Local Councils, Durban 2004 (3) SA 223 (N).

1052012 (4) SA 207 (SCA). 
the spoliation was unlawful. In this context a restrictive interpretation of the authorising provisions would have preferred, in the first instance, the restriction of the electricity reticulation supply to the applicant's home.

\section{Masinda}

Masinda is problematic for a few reasons. The first relates to the obiter remarks by Leach JA regarding to operation of the spoliation order that the court $a$ quo granted the respondent. He is probably correct that it could not have been the intention of the court a quo to order the restoration ante omnia of a connection 'that was unlawful and a danger to the public.' However, Zinman $v$ Miller ${ }^{106}$ provides ample authority for the proposition that the spoliator can be ordered to do something more than restoring the property to its former state which could easily include restoring possession in such a manner that it complied with the necessary requirements of safety. Furthermore, the court's reasoning that the purpose of the spoliation remedy does not include the restoration of a 'reconstituted equivalent' of the specified property probably does not hold water either. Blecher ${ }^{107}$ and Van der Walt ${ }^{108}$ persuasively argues with reference to Fredericks $\checkmark$ Stellenbosch Divisional Council ${ }^{109}$ that the spoliation remedy could be applied outside of its traditional restorative framework in the specific circumstances where the property was destroyed on purpose to frustrate a restoration order and where the destroyed property was fungible. ${ }^{110}$ It is likely that the appellant's teams removed the illegal connections deliberately to frustrate the operation of the spoliation remedy in the interests of the owners' safety and well-being. However, an argument can be made that the electrical installations

1061956 (3) SA 8 (T). In this case the appellant, an electrical engineer, removed the main panel from the electrical meter chamber and cut the electrical wiring so that there was no flow of electrical current in the respondent's, the owner of the property, house. The court a quo found that it had no jurisdiction to decide the case in terms of section 46(2)(c)(ii) of the Magistrate's Courts Act 32 of 1944. On appeal Rumpff $\mathrm{J}$ found that section 46(2)(c)(ii) of the Act did not limit the jurisdiction of the magistrate to grant the extraordinary remedies of a temporary nature provided for in section 30(1) of the Act. Section 30(1) provides that '[s]ubject to the limits of jurisdiction prescribed by this Act, the Court may grant against persons and things orders for arrest tanquam suspectus de fuga, attachments, interdicts and mandamenten van spolie.' Rumpff J (at 12) confirmed that the purpose of the mandament van spolie was to restore possession ante omnia and therefore could include an order for 'something to be done in addition to the mere putting of the spoliated back in possession of the thing spoliated.' In this case the mandament van spolie required the replacement of the main panel and the reconnection of the electrical wires.

107 Blecher MD 'Spoliation and the demolition of legal rights' (1978) 97 SALJ 8-16.

108 Van der Walt AJ 'Developing the law on unlawful squatting and spoliation' (2008) 125 SALJ 24-36; Van der Walt AJ 'Nog eens Naidoo v Moodley - 'n repliek' (1984) 47 THRHR 429-439 and Van der Walt AJ 'Naidoo v Moodley: Mandament van spolie' (1983) 46 THRHR 237-240.

1091977 (3) SA 113 (C). 
do not have any unique characteristics that would preclude its replacement with generic substitutes of equal weight, measure and number.

Second, in holding that the supply of electricity itself is not an incident of occupation, the court perpetuates the line of case law, which began with Telkom SA Ltd $v$ Xsinet (Pty) Ltd, ${ }^{111}$ where the Supreme Court of Appeal created confusion as to how exactly the protection of quasi-control works. In Masinda the court continues this line of reasoning as follows:

In order to justify a spoliation order the right must be of such a nature that it vests in the person in possession of the property as an incident of their possession. Rights bestowed by servitude, registration or statute are obvious examples of this. On the other hand, rights that flow from a contractual nexus between the parties are insufficient as they are purely personal and a spoliation order, in effect, would amount to an order of specific performance in proceedings in which a respondent is precluded from disproving the merits of the applicant's claim for possession. ${ }^{112}$

In considering the rights of the applicant during the possessory suit the court negates the speedy nature of the remedy which precludes a consideration of the merits.

Third, contrary to what the court held in Masinda, the applicant's claim was not "terse". In his judgment Leach JA refers to the fact that the applicant used purchased electricity using a card with a number that corresponded with the number of the electricity meter; that a vendor supplied her with a voucher that contained a unique code on it; that she punched the code into the pre-paid electricity meter which then registered a credit; and that she then drew electricity from the national grid through the meter into her home. ${ }^{113}$ This 'outward manifestation,114 of her factual use of electricity presents incontrovertible evidence in support of her claim that she had quasipossession of the electricity reticulation supply to her home. To this extent her claim was appropriately framed and abundantly evidenced.

Finally, Masinda could arguably have been decided along a different line of reasoning. In this alternative arc the court should have acknowledged that the applicant was in peaceful and

110 Fungible things belong to a certain generic class of things that can be replaced by any other similar thing. They do not have any characteristics that make them so unique as to be considered irreplaceable. In trade, fungible things are often referred to in terms of weight, measure or number. Non-fungible things are considered irreplaceable because they have unique characteristics or value. See Van der Merwe CG Sakereg (2nd ed 1989) 43; Van der Merwe CG \& De Waal MJ The Law of Things and Servitudes (1993) 22.

1112003 (5) SA 309 (SCA).

112 Masinda par 22.

113 Masinda paras 5 and 23.

114 Bon Quelle (Edms) Bpk v Munisipaliteit van Otavi 1989 (1) SA 508 (A) at 514I. 
undisturbed possession of the electricity reticulation supply to her home. However, the court should have precluded the operation of the spoliation remedy with reference to the defence that it is impossible to restore illegal possession ${ }^{115}$ of electricity reticulation to the applicant's home. The court noted that the application of section 25 of the ERA was in dispute, but it could have reasoned that the installations were not made by a licensee ${ }^{116}$ that operated under the peremptory conditions of ensuring compliance with 'health, safety and environmental standards and requirements.'117

\section{Conclusion}

The preceding analysis reveals that it is possible to protect access to services in terms of another distinct property principle - namely, protecting quasi-possession of use rights as incidents of occupation with the spoliation remedy. The applicant will have to show the she used the electricity reticulation in her residence. This outward manifestation of the factual use of these services should allow the applicant to appropriately frame a claim that the spoliator interfered with or took over control of her right. In Masinda the Supreme Court of Appeal decided to perpetuate the flawed line of reasoning that it adopted in Telkom. In this article I showed why this reasoning is problematic and proposed an alternative arc along which the court should rather develop its jurisprudence on the application of the mandament van spolie for purposes of electricity. In doing so the court can reaffirm, as the high courts did in Froman and Naidoo, the robust and speedy nature of the spoliation remedy and its ability to swiftly and effectively restore the applicant to the factual position she was in before the dispossession. However, the relief will only be temporary and she should use the time to formulate a claim based a servitudal right or a statutory use right.

115 See Boggenpoel ZT Property Remedies (2017) 142-149 and the sources cited there for an authoritative analysis of this defence.

116 Section 7(1)(a) of the ERA.

117 Section 14(1)(s), read with section 14(1)(n), of the ERA. 